\title{
ETHNIC STYLE IN THE CONTEMPORARY ART OF CRIMEA
}

\author{
N.M. Akchurina-Muftieva \\ Crimean Engineering and Pedagogical University \\ Simferopol, Russian Federation \\ akchurina_05@mail.ru
}

Research objective: To provide an art history analysis of the interpretation of ethnic motifs in the modern art of Crimea. Recently, among contemporary decorative artists in Crimea, there has been a surge in the revival and use of Crimean Tatar national symbols. Over the past fifteen years, there has been an active search for a peculiar Crimean style, expressed through the interpretation and stylization of ethnic motifs in decorative and applied art.

Research materials: The fact that a great number of very interesting, colorful works appeared is connected with the publication of research works related to the practically forgotten Crimean Tatar arts. The analysis was carried out on the basis of the exhibitions of "Crimean style" by the creative association "Chatyr-Dag" (since 2005) and diploma works of students of the Crimean Engineering and Pedagogical University.

There is an active use of motifs such as "the tree of life" and "the flowerpot", symbolizing family and its continuity. The decor of modern ethnic costume includes ornamental motifs of the curled branch "Egri-dal", paradise gardens, flowers and fruits. Stylized floral motifs fill the surface of ceramic products, jewelry, embroidered and painted textiles intended for interior design.

Arabic calligraphy, often included in ornamental compositions of decorative products, has found a wide reception in the modern practice of products decoration. At the present time, however, calligraphy on the products is more often "painted" than written, and, as a rule, it performs a decorative rather than semantic function.

The novelty and the results of the research: Taking into consideration modern points of view on life and mutual influence of cultures, the usage of ethnic symbols in works of contemporary artists is accompanied by a significant interpretation of their meaning, semantic context and their placement on products. As a result, the influence of Uzbek and Ukrainian (Slavic) cultures is noticeable. This is manifested in the use of new ceramics and textile panels in contrast to traditional techniques of embroidery. In the imaginative choice of motifs, shades of a Central Asian style can be traced. There is a new interpretation of the motifs, explained by the influence of Ukrainian culture.

Keywords: decorative arts, ethnic motifs, modern artists, Crimean Tatar culture

For citation: Akchurina-Muftieva N.M. Ethnic Style in the Contemporary Art of Crimea. Zolotoordynskoe obozrenie=Golden Horde Review. 2018, vol. 6, no. 3, pp. 569-578. DOI: $10.22378 / 2313-6197.2018-6-3.569-578$

During the whole visible history of the Crimean Peninsula, the active migrations of tribes and peoples were taking place, replacing each other. Each ethnic group, settled on this land, brought its own characteristic traits that were peculiar to the common life of Crimea. Their creative activity not only preceded the formation of Crimean Tatar arts, but also organically took part in the process of its emergence. Variety of used artistic and technical means, ornaments and different artistic 
styles led to the multi-layer content and picturesque, complex style, characteristic for the works of the Crimean Tatar applied arts. Such kinds of arts and techniques of processing materials is evidenced in gold embroidery, patterned weaving, filigree, carvings and paintings on stone and wood.

Since the adoption of Islam, during the long historical period, artistic culture of Crimean Tatars has developed in the form of ornamental creative work and traditional artistic handicraft. Style tendency of creative work followed aesthetic canons of Islamic culture. Ethnic traditions reflected its influence, thus forming national aspect of the Crimean Tatar style.

Until the beginning of the $20^{\text {th }}$ century, the life of Crimean people was surrounded by handmade objects: the poor used simple ones, the rich ordered goods from the best artisans. Already in the middle of the third decade of the last century, the cheap manufacturing production finally forced out the handmade goods from the everyday life, leaving it a place among the souvenir crafts. The famine of 1921-1922 in Crimea made a shattering blow on traditional folk handicraft industry: pottery, jewelry, carving and engraving works, embroidery, production of fabric, carpets, brass dishes and many other things. Many artisans simply did not survive that period.

After the October Revolution, the way of live of Crimean Tatars and their needs sharply changed. The inner necessity of luxury goods was not so great, and that was one of the reasons for the crisis of the folk arts. Simplification of the everyday life brought the situation to the point when the handmade goods, even of very high artistic value, could not find their customers. In addition, it seemed that after the deportation there were no heirs left of those artists either. Deportation from Crimean Peninsula and discrimination that lasted many years, deprived Crimean Tatars of their Motherland. The destruction and oblivion of their cultural achievements caused by the Soviet State, brought tragic and irreversible loses for the national culture.

The process of restoration of national traditions, experiences and skills, is one of the most important parts of the modern life. Due to the spiritual heritage of old, the modern arts are still alive and continue to develop. Today, when the greater part of Crimean Tatars has returned to the Motherland, restoration of their national cultural heritage has become especially important, being connected with the problem of self-identification in the modern world.

After 40 years of exile, the art of Crimean Tatars began its development with a clean slate. Modern artists had a chance to develop their trade forgotten by others, not constrained by traditions and being very original at the same time. However, it was the time to learn the people's lost heritage and to restore ethnic memory and traditions of their ancestors. The exhibitions of modern Crimean Tatar applied arts, opened for the first time in 2005, are becoming richer and broader each year. The names of many artists, masters of embroidery, ceramics, carving, engraving, painting and jewelry became very famous, and only now we can track down and talk about new tendencies and traditions in modern Crimean Tatar decorative arts.

At present, there is a surge of restoration and usage of Crimean Tatar folk symbols among modern artists of decorative arts in Crimea. During the last fifteen years, on the basis of ancient traditions of Crimean Tatar culture, there is an active search towards the peculiar modern Crimean Tatar style, being expressed through 
interpretation and stylization of ethnic motifs in ceramics, embroidery, application works and textile panels in modern dress.

The fact that a great number of very interesting, colorful works appeared is connected with the publication of scientific research works related to the practically forgotten Crimean Tatar arts. Attempts of specialists to restore understanding and perception of Crimean Tatar symbols $[1 ; 2 ; 3 ; 4]$, and implementation of the project "Crimean Style" by "Chatyr-Dag" creative union, opened wide horizons to young modern artists of applied arts.

Today we are increasingly turning to the sources, through the use of elements of decorative applied arts (ceramics, embroidery, jewelry) in everyday life. Folk style became fashionable, original and attractive when organically combined with the interior design, while handmade elements of dresses are considered distinct and attractive. Therefore, the works of modern artists also rely on ancient arts and its traditional symbolism.

The main sources of Crimean Tatar motifs are those rare patterns of embroidery from the end of the $18^{\text {th }}$ - first part of the $20^{\text {th }}$ century, preserved up to our days. Tendencies of the Crimean style in decorative arts are based on the usage of ethnic motifs on objects made from natural materials, its interpretation and its influence to the depth of our subconscious.

The favorite and most popular motifs became "the tree of life" and "the flowerpot", symbolizing family and its development. Among the Crimean Tatars, the tree is related to the life of a whole family and its welfare. This motif was prominent in Crimean Tatar embroidery and had the meaning of wishing to a man a physical, masculine power, stability, welfare, fertility, continuation of a family (kin) [1]. The presence of symmetry in portrayal of a family tree, which implied stability with a masculine sign in the center, and feminine and children' signs on the edges, defined it as a family coat of arms - an amulet, a sign of peace, equality, happiness and flourishing of a family [5]. The same symbolic meaning has "the flowerpot". In its basis there is a tree, growing from the jug, vase, basket or kettle, signifying the house in which the family lives.

The modern Crimean artists often use the motif of the tree of life, as an amulet and in the design of interior textile: on wall panels, small carpets and pictures, made in mixed techniques. Different compositions and variations of the theme "the tree of life" and "the flowerpot" are also successfully used in textile painting, mosaic and decorative ceramics.

Mamut Churlu is one of those that stick to the tripartite structure of the tree with nine main elements in his works (ill.1). In his panels, made in mixed technique of application and embroidery, the author's approach to the stylization of motifs and strengthening of color contrasts is evidently noticeable. The same manner of color decisions can be traced in decorative ceramics made by R. Skibin. Brightness and expressiveness of paints and polychromatic shines attest the influence of Uzbek culture on the creative work of those artists who, during the long period of deportation, were influenced by that culture.

Figurative symbols, usage of folk ornaments, flattened representation, decorativeness and brightness of color decisions, assimilation of Crimean Tatar ornaments with experience of Ukrainian native artists, as well as technique of Uzbek suzani art, are quite characteristic for decorative panels made by Julia Tulupova: "the tree" and "the flowerpot" in her works are transformed into blossoming bush, 
in the basis of which are the depictions of cypress, tulip and pomegranate fruit (ill.2).

The tree motifs are widely used in embroidery of modern production of souvenirs and presents, made by women of the "Evgiyar" association from Bakhchisaray. Purses, cosmetics bags, covers for cellphones, gift hats $(f e s)$, covers for the Quran and small pictures in frames, are embroidered in high technique of sewing in golden and silver threads, and through the use of beads, pearls and spangles. As a rule, bright velvet of red, blue, purple, green or black colors is chosen for the products.

As we can see, the fact that Crimean Tatars lived for a long time on the territory of Uzbekistan had its impact in bringing into their arts the elements of Uzbek culture. It is reflected in:

- the usage of stitches and methods of Uzbek suzani in embroidery;

- the change of color of decorative products towards the more bright and contrastive;

- the usage of enlarged elements in ornamental compositions;

- the implementation of large-scale embroidery and combined panels for the living interior.

Ornaments on cloth and garments among the Crimean Tatars have its own symbolic and sign system, connected with religion, customs and cultural traditions. The most widespread are the symbols of plants: fruits, grain, grape, vine and various flowers. Numerous fruits (especially pomegranate, grape and pear) in ornaments symbolize the wishes for wealth, fertility and success; in the spiritual sphere they symbolize the wishes for wisdom.

In Muslim arts, allegory of flowers was used to portray a man, among which a rose was a symbol of a man in the bloom of life and spiritual power. Crimean Tatars made this motif on a female head cover marama, signifying love, beauty, grace, perfection, happiness. The other widely spread motif is a tulip. The tulip signified a youth, a man offering his "declaration of love" and it was often depicted in the center of the "tree of life", on the Quran cases, on tobacco pouches, or the male wedding waistbands.

These ornamental motifs are nowadays used by the artists in embroidery of interior textile (pillows, bed covers), details of garment or souvenir products (covers for cell phones, bags or purses). Depictions of tulips are often used in gold and silverware.

Having learnt the restored traditional Crimean Tatar sewing, modern female artists create an endless number of ornamental variations by combining them with pearls, spangles and especially with beads, as well as by using new methods. Gold embroidery on velvet (red, green, violet) on saturated rich fabric became particularly prominent. The passion for contrasts of bright, shining gold and dark velvet, rather confirms the influence of Uzbek culture than Crimean Tatar traditions, in which such variations could only have been present in holiday attire of rich citizens.

In Islamic arts, one can often see depictions of nature, mostly images of gardens. In the memory of the people, the recollections of magnificent Hanging Gardens of Babylon are still kept. Great royal parks of the Iran's Sassanid epoch, the firdaws or paradise, were imagined as wonderful gardens. For Muslim people the paradise is the end of the road. 
In Crimean Tatar art, "Egri-dal" ornament - a curled branch, full of great number of different flowers and fruits - symbolizes the Garden of Eden, endless flourishing, eternal harmony and perfection to which they are striving for and which is deserved by the souls of people who lived righteous life. The basis of ornament composition is the "S"-shaped line-branch, onto which, the flowers of roses, tulips or carnations are inserted, without being repeated. In the material world, such a mixture of different flowers on one branch is impossible. However, in this way the world in which there are the other laws is revealed; there is not extension of time from past to future, but rather the past, future and present are interconnected in a whole. All points of space are simultaneously visible from all points of time.

The motifs of flowers, fruits and paradise gardens, together with their symbolic context, are reflected in the design of modern ethnic attire. Embroidery, painting, jewelry, stylized with traditional Crimean Tatar motifs, have become inseparable part of modern ethnic and everyday dress, as well as garments for weddings and other ceremonies. This is the working sphere of students and graduates of the Crimean Engineering and Pedagogical University. By using historical and cultural experience of folk traditions, they restore the original and unique beauty of national dress and create highly artistic exhibition patterns and modern models in ethnic styles (ill.3).

Flower motifs are widely used by artists in ornamentation of ceramics and textile for interior usage. These include tablecloths, napkins, towels, bed covers, sofa pillows and embroidered wall carpets, made by masters from Bakhchisaray, Belogorsk and Simferopol (ill.4).

A very interesting motif in the Crimean Tatar embroidery is the depiction of sailing vessels with paradise gardens on them. Some parts of ships are depicted like a boat on which there is a blossoming paradise garden and cupolas of oriental palaces are visible. The forms of ships are different: they look like a carrying pole, the upturned letter " $\Pi$ " or a triangular tent. However, in all those cases, the flowers are blooming, cypresses are stretching high, paradise apples grow, and there is also the prophetic bird Roc in the shape of a trefoil [1].

The theme of the Garden of Eden found its reflection in decorative works of modern artists: embroidered applications, ceramics and woven panels. The Eden was imagined by the contemporaries like a city, situated under huge, fruit bearing tree and resembling the Crimea of old and present times. The city, with multicolored minarets, paradise trees, flowers and birds, is covered with multiple stars and crescents - Islamic symbols of eternity, high aspiration and ideals. I. Patrakova depicted the Crimean Peninsula as a corner of such paradise, on decorative adornment made in technique of two-side Crimean Tatar embroidery. Fantastic island, located in a bowl, is surrounded by two seas. There are blossoming gardens, high minarets and blooming tulips. The sun shines and Peace and Grace reign on the island. Crimea is a Garden of Eden, and for many Crimean Tatars it is the end of a long journey back to the Motherland (ill.5).

The same presentation of the Crimean Peninsula as a Garden of Eden can be traced in the works of young, contemporary artists, made in the technics of ceramics, applications, embroidery and tapestry. This is how young artists, for whom the religion is not of paramount importance, understand the symbolic paradise. Moreover, new images appear, as well as new interpretations of motifs, which can be explained by the influence of Uzbek and Ukrainian (Slavic) culture. Thus, in the works of Mamut Churlu there are depictions of durbe with blue cupolas, while horses were portrayed as literally coming down from oriental miniatures. In the 
graphic works of young artist E. Gusenov, the paradise is depicted as a ship with mihrab, hovered by two "angels" (good and evil) in the form of stylized birds, present in the ancient Crimean Tatar ancient embroidery.

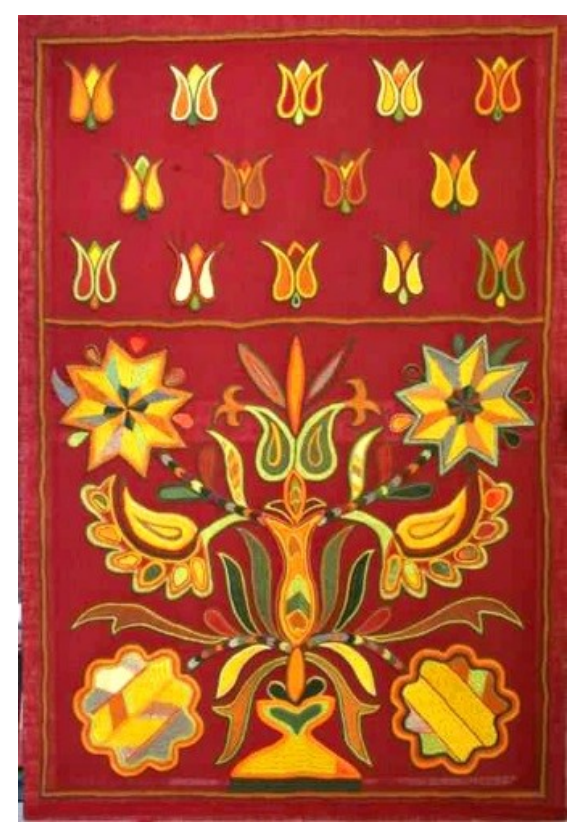

Ill.1. Mamut Churlu. The Tree of life. Panel. Embroidery

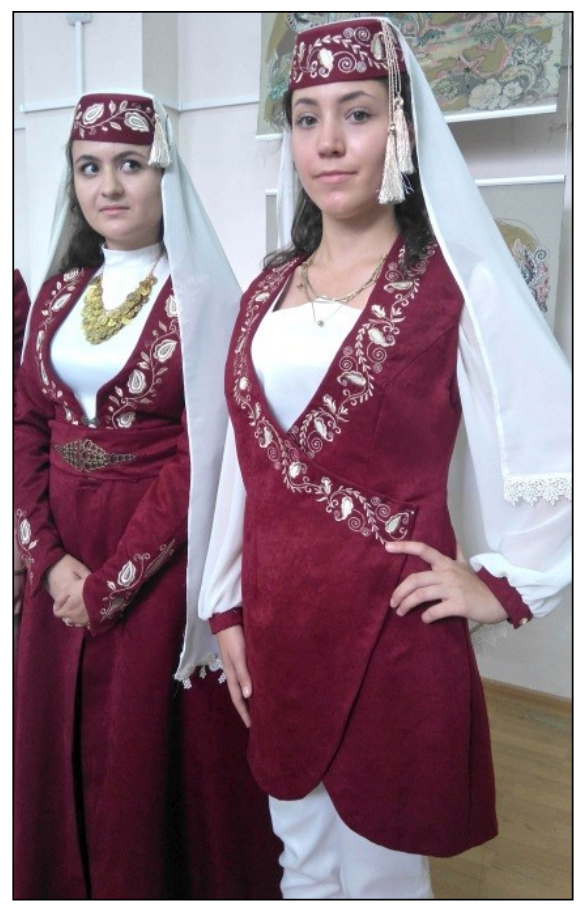

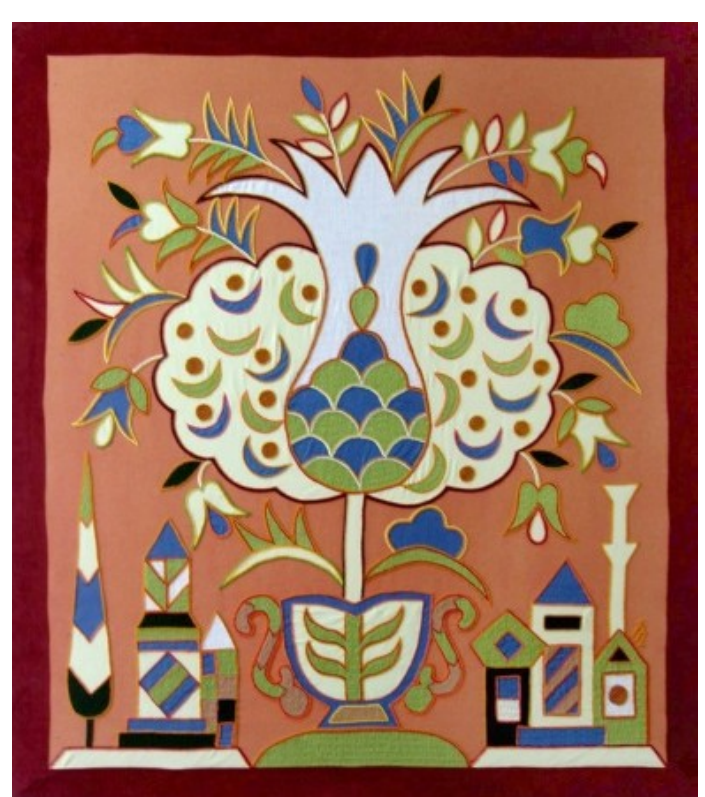

Ill.2. Julia Tulupova. The tree. Panel. Mixed techniques: applique, embroidery

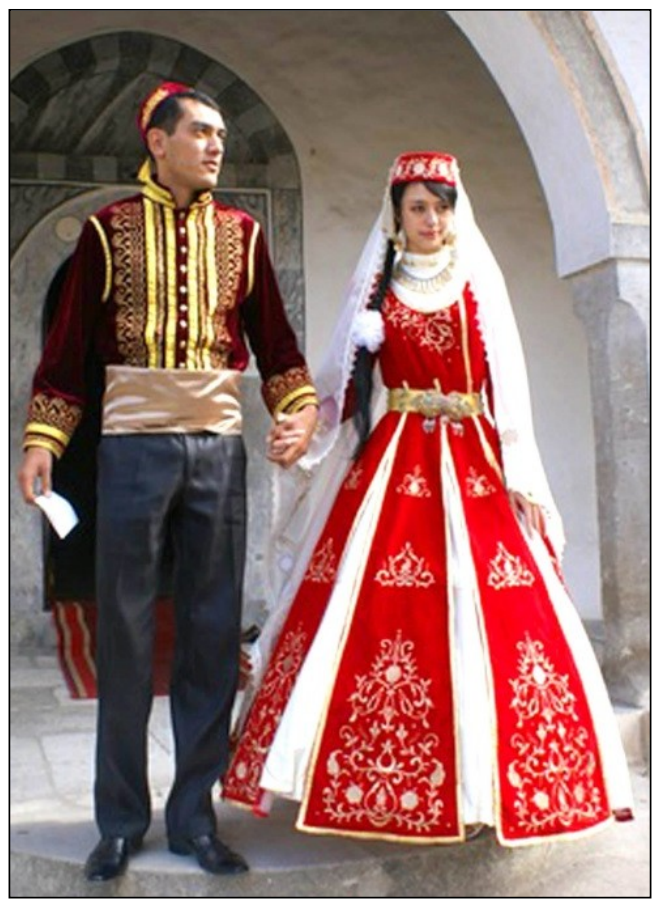

Ill.3. Design of modern ethnic costume. Graduation thesis. Crimean Engineering and Pedagogical University 


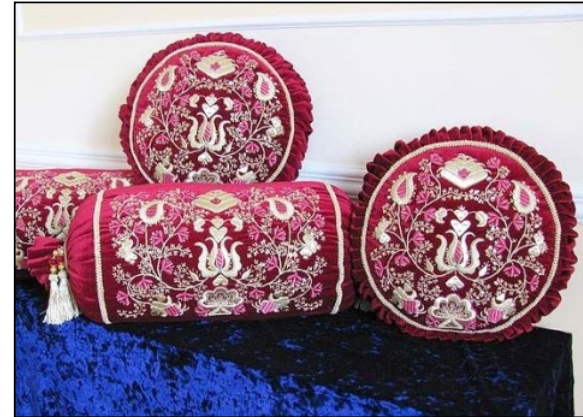

a)

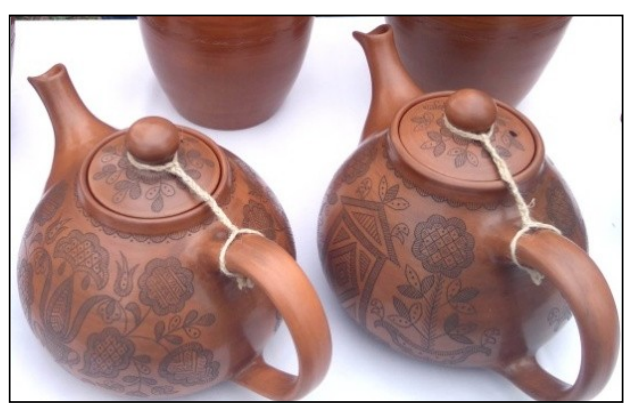

b)

IIl.4. Floral motifs in the ornamentation of ceramics and textiles for interior: a) H. Yunusova; b) E. Gusenov

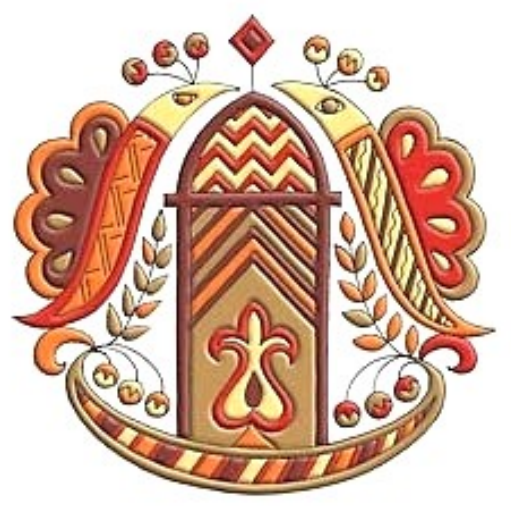

a)

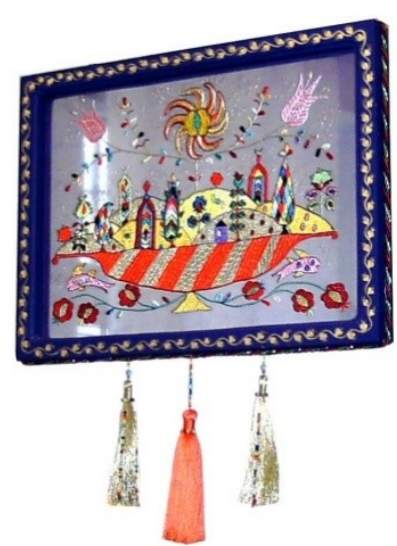

b)

Ill.5. Garden of Eden:

a) E. Gusenov; b) I. Patrakova

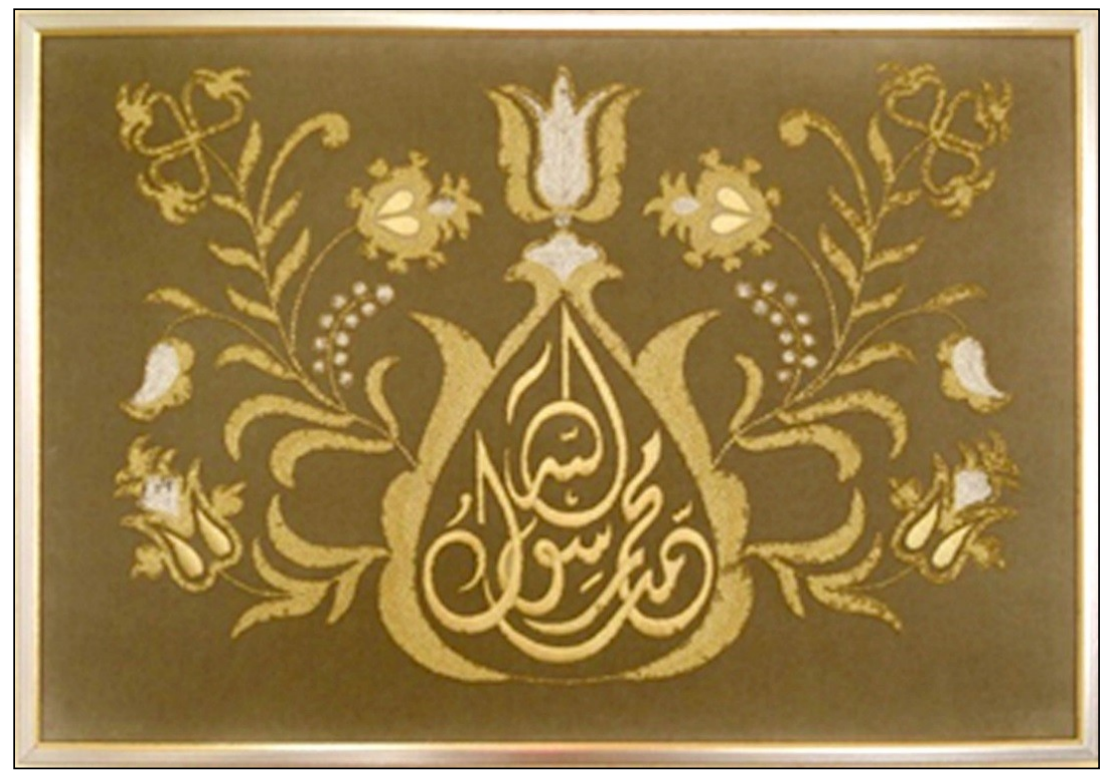

Ill.6. Arabic calligraphy. L. Muratshaeva. Panel. Gold embroidery, beads 
The appearance of "Epigraphic monuments", different kinds of calligraphic writings, monograms and portrayals, which used graphic and plastic traits of Arab alphabet letters, refers to the pre-Golden Horde's period in Crimea. The symbolic functions of the Arabic script include not only the transmission of a specific message, but also a much more important task - the transfer of the sacred functions of the Arabic language as the language of revelation, embodied in the words of the Quran. Arab graphics should be considered embodiment of the Divine beauty and its creation. That is why calligraphic script has become artistic means present on all levels of the Muslim civilization. The prayers engraved, embroidered, carved or written on household utensils were used as talismans, in which magic power our ancestors believed.

In our days Arabic calligraphy is reflected in modern practice of decorative ceramics, embroidery, carvings on wood, engravings on metal and also in the design of polygraph products. However, calligraphy on these products is rather "painted" than written, and, as a rule it performs a decorative, and not a semantic function.

The students of the Faculty of Arts of the Crimean Engineering and Pedagogical University made several decorative panels, combining in them stylization of the tree motif symbolizing the host's kin (family) and calligraphic inscriptions of the prayer, organically inscribed in the motif of the tree (ill. 6). Such works fit well in modern ethnic interior, emphasize the national flavor and simultaneously perform the function of an amulet, a talisman and the interior decoration.

In the works of young artists, the use of ethnic symbols, together with modern views on life and the interaction of cultures, occurs with a significant interpretation of their meaning, the semantic context and placement on products. The influence of Uzbek culture on Crimean Tatar culture during the deportation period, as well as the influence of Ukrainian culture during the last two decades, led to the adoption of new techniques, different from the traditional ones, in decorative arts, embroidery, ceramics, woven and textile panels. Figurative depiction of motifs reveals the traces of Middle Asian arts. The new interpretation of motifs by modern artists is explained by the influence of Ukrainian (Slavic) culture. Today, the decorative art items, carry the gleam of the past and reflect the contemporary vision of the artists of the cultural heritage of Crimean Tatars - the indigenous people of Crimea. Many kinds of folk arts, including weaving, embroidery, ornamental painting, jewelry, ceramics, calligraphy, engravings on metal, carvings on wood, and leather workings, were brought to life with the return of Crimean Tatars to their historical Motherland. Due to the selfless, devoted work of outstanding, original artists, after tens of years passed by, the world is now convinced that no kind of deportation could destroy innermost creative knowledge and the deeds of skillful hands, cherished for ages on the Crimean soil. Colored kilims, multi-colored and gold embroideries, painted ceramics and jewelry made by Crimean masters reveal the warmth and brightness of the Crimean sun, magnificence of its mountains, the beauty of its nature, the unique flavor and the identity of the Crimean Peninsula. The culture of Crimea is not only the property of the Crimean people, but of the whole world as well. That is why the preservation and continuation of this precious heritage is one of the ways to keep mutual understanding among peoples, enrichment of their cultures, and is also the solution to most of the contemporary acute problems. 


\title{
REFERENCES
}

1. Akchurina-Muftieva N.M. Dekorativno-prikladnoe iskusstvo krymskih tatar XVpervoj poloviny $X X v v$. [Crimean Tatar Decorative-Applied Arts of the $15^{\text {th }}$ - beginning of the $20^{\text {th }}$ centuries]. Simferopol, Simferopol city printing house, 2008. 456 p. (In Russian)

2. Akchurina-Muftieva N.M. Terminologicheskij slovar' krymskotatarskogo dekorativno-prikladnogo iskusstva [Terminological Dictionary of the Crimean Tatar Arts and Crafts]. Simferopol, Uchpedgiz, 2007. 140 p. (In Russian)

3. Kurtiev R.I. Tyurkskie simvoly $\mathrm{v}$ tradicionnoj kul'ture krymskih tatar [Türkic Symbols in the Traditional Culture of the Crimean Tatars]. Bahchisarajskij istorikoarheologicheskij sbornik [Bakhchisaray Historical and Archaeological Collection]. Simferopol, 2001, pp. 444-448. (In Russian)

4. Sultanbekov R.T. Krymskotatarskaya simvolika: opyt slovarya [Crimean Tatar Symbols: Dictionary Experience]. Simferopol, 2002. 54 p. (In Russian)

5. Churlu M.Yu. Simvol Raya [The Symbol of Eden]. Pyatye krymskie iskusstvovedcheskie chteniya. Materialy respublikanskoj nauchno-teoreticheskoj konferencii [The Fifth Crimean Readings of Art Criticism. Proceedings of the Republican Scientific and Theoretical Conference]. Simferopol, 2000, pp. 31-32. (In Russian)

About the author: Nuria M. Akchurina-Muftiyeva - Doctor of Arts, Professor, Department of Decorative Arts of the Crimean Engineering and Pedagogical University (8, Uchebnyj lane, Simferopol 295015, Russian Federation). E-mail: akchurina_05@mail.ru

Received June 5, 2018 Accepted for publication September 3, 2018 Published September 29, 2018

\section{ЭТНОСТИЛЬ В СОВРЕМЕННОМ ИСКУССТВЕ КРЫМА}

\author{
Н.М. Акчурина-Муфтиева \\ Крымский инженерно-педагогический университет \\ Симферополь, Российская Федерачия \\ akchurina_05@mail.ru
}

Цель исследования: искусствоведческий анализ интерпретации этнических мотивов в современном искусстве Крыма. В последнее время в среде современных художников декоративного искусства в Крыму наблюдается всплеск возрождения и использования крымскотатарской народной символики. На протяжении последних пятнадцати лет идет активный поиск своеобразного крымского стиля, выражающегося через интерпретацию и стилизацию этнических мотивов в декоративно-прикладном искусстве.

Материаль исследования: появление большого количества интересных творческих работ связано с выходом публикаций научных исследований забытого крымскотатарского искусства. Анализ проведен на основе выставок «Крымского стиля» творческого объединения «Чатыр-Даг», начиная с 2005 г., и дипломных работ студентов Крымского инженерно-педагогического университета. 
Наблюдается активное использование мотивов «древо жизни», «вазон», символизирующих семейный род и его продолжение. В декор современного этнического костюма включаются орнаментальные мотивы изогнутой ветки «эгри-дал», райских садов, цветов, плодов. Стилизованные цветочные мотивы заполняют поверхности керамических изделий, ювелирных украшений, вышитого и расписного текстиля интерьерного назначения.

Арабская каллиграфия, часто включавшаяся в орнаментальные композиции декоративных изделий, нашла широкое отражение в современной практике декора продукции. Однако в настоящее время каллиграфия на изделиях чаще «рисованная», а не написанная, и, как правило, выполняет функцию декоративную, а не смысловую и обереговую.

Результаты и научная новизна заключаются в определении репрезентации национальной символики в современном искусстве Крыма. В работах молодых художников использование этнических символов, с учетом современных взглядов на жизнь и взаимовлияний культур, происходит со значительной интерпретацией их значения, смыслового контекста, размещения на изделиях. В результате заметно влияние узбекской и украинской культур. Это проявляется в использовании новых, в отличие от традиционных, техник в вышивке, керамике, текстильных панно. В образном решении мотивов прослеживается оттенки среднеазиатского стиля. Возникает новая трактовка мотивов, объясняющаяся влиянием украинской культуры.

Ключевые слова: декоративное искусство, этнические мотивы, современные художники, крымскотатарская культура

Для цитирования: Akchurina-Muftieva N.M. Ethnic Style in the Contemporary Art of Crimea // Золотоордынское обозрение. 2018. Т. 6, № 3. С. 569-578. DOI: $10.22378 / 2313-6197.2018-6-3.569-578$

Сведения об авторе: Нурия Мунировна Акчурина-Муфтиева - доктор искусствоведения, профессор кафедры декоративного искусства ГБОУ ВО РК «Крымский инженерно-педагогический университет» (295015, переулок Учебный, 8, Симферополь, Российская Федерация). E-mail: akchurina_05@mail.ru 